Vol. 3, No. 1, 2016

UDC 339.5:330.23

\author{
O. V.Pyrog \\ Doctor of Economic Science, Professor,
}

A. I. Horyachka,

Bachelor of International Economics,

Lviv Polytechnic National University

\title{
THE DEVELOPMENT OF E-COMMERCE IN TERMS OF VIRTUALIZATION INDUSTRY
}

\begin{abstract}
The article focuses on the analysis of the virtual economy, global trends in e-commerce, market size of e-commerce and the prospects of their development. Innovations in e-commerce, industry 4.0, which is a profitable platform for investments from around the world, are presented.

Key words: e-commerce, virtual economy, real economy, Internet, Internet sector, online stores, virtualization industry, industry 4.0, Ukraine.

\section{Problem statement}

E-commerce is developing rapidly, but there are several issues of e-business. Firstly, intense competition dooms to failure many start ups in the field of e-business. Secondly, because some online sellers deceive customers the demand for virtual goods is reduced. Today the key issues are the protection of buyers' rights on the Internet and the constant improvement of Internet relationship regulation. The most urgent issue in Ukraine is the introduction and popularization of Internet wallets. As there are only some sites that provide the option of paying with electronic purse, most goods are still being sent by post with overhead payment increasing the cost of online product and therefore reducing demand for online purchasing.
\end{abstract}

\section{Analysis of recent research and publications}

The important contribution to defining e-commerce was made by such scholars of western schools as B. Busto, E. Vilkas, K. Kendall E. McCarthy, B. Marshall, E. Melz, K. Rihelsford, P. Steynbart, I. Sharp and others. Ukrainian and Russian scientists also investigated some issues of electronic commerce, among them are: O. Bilyachenko, N. Buzak, H. Litvak, G. Negoda, L. Timchenko, V. Rudnytsky, N. Chebanov, L. Yanchev. The current state and trends of e-commerce in Ukraine have been investigated in research works of A. Kudinov and A. Kredenets.
N. Chuchko [4] and G. Lozikova have been researching the development of electronic commerce in international economic relations. The article of M. Vozny [5] identified the importance of international e-commerce in the global economy, the basic trends of its development, the analysis and dissemination of international electronic commerce in Ukraine. However, the given data in the publications are already out-of-date, therefore there is a need for researching new trends in this area as the development of the information economy is growing rapidly.

Research objective is to study the current state of e-commerce market and identify the main trends of development in the world and specific regions.

\section{Research material}

The real sector of economy is an integral part of modern economic systems, which plays a major role in ensuring sustainable economic development and social welfare state. At present it holds key positions in economies of many industrialized countries. Thus, for example, it accounts for $54,5 \%$ of GDP in the UK, $57,1 \%$ in Japan, $40 \%$ in the USA and $68 \%$ in China. The essence of the virtual model is that instead of administrative methods by which the cost was transferred from the first to the second sector, in modern pseudo-market systems there are various successfully operating non-market forms of payments: promissory notes, barter, debt trading. The above model is based on current numbers and facts of Ukraine. At present barter and other forms of non-cash payments exceed $40 \%$ of payments for industrial products. Tax debt payment of entities is 10 billion, wage, pension and other budget transfers account for 8,5 billion. A comparison of virtual and real economies is presented in Table 1 . 


\section{O. V. Pyrog, A. I. Horyachka}

Table 1

\section{Comparison of virtual and real economies}

\begin{tabular}{|l|l|}
\hline \multicolumn{1}{|c|}{$\begin{array}{c}\text { The virtual economy, } \\
\text { economy online }\end{array}$} & \multicolumn{1}{|c|}{$\begin{array}{c}\text { Real economy, } \\
\text { economy offline }\end{array}$} \\
\hline $\begin{array}{l}\text { Fields of activity: trade, } \\
\text { services; }\end{array}$ & $\begin{array}{l}\text { Fields of activity: agricul- } \\
\text { ture, industry, building, } \\
\text { transport, trade, services; }\end{array}$ \\
\hline $\begin{array}{l}\text { mainly unavailable control } \\
\text { and licensing system, without } \\
\text { paying bribes corruptionists; }\end{array}$ & $\begin{array}{l}\text { continuous problems with } \\
\text { licensing and controlling } \\
\text { systems; tax and other state } \\
\text { control bodies require } \\
\text { regular bribes, or close } \\
\text { down the real business; }\end{array}$ \\
\hline $\begin{array}{l}\text { you do not need to rent or } \\
\text { buy office space, work is in } \\
\text { online mode (modern office- }-\end{array}$ & $\begin{array}{l}\text { you need to spend money } \\
\text { on offices and have addi- } \\
\text { is no office); } \\
\text { firefighters, sanitary sta- } \\
\text { tions; hire and provide } \\
\text { security; face with the risks } \\
\text { of raiding and racket; }\end{array}$ \\
\hline $\begin{array}{l}\text { slower calculations; } \\
\text { faster calculations; }\end{array}$ & slower customer services; \\
\hline faster customer services; \\
\hline $\begin{array}{l}\text { employees work in comfor- } \\
\text { table environment, at home } \\
\text { or resort with access to the } \\
\text { Internet; }\end{array}$ & $\begin{array}{l}\text { employees work at the } \\
\text { office; }\end{array}$ \\
\hline $\begin{array}{l}\text { chief is not tied to the } \\
\text { workplace, manages compa- } \\
\text { ny online; }\end{array}$ & $\begin{array}{l}\text { chief must be at the office; } \\
\text { lovel of the company is the planet. }\end{array}$ \\
the local economy, town. \\
\hline
\end{tabular}

Subjects of interactive economy are businesses, consumers and a state. Virtual economy as a market economy is characterized by tough competition. First of all image and competitiveness of the economy is provided by reputation and rankings of entities. Market signals, entity's image and various sureties and guarantees are mechanisms of interactive economy.

The main trends of e-commerce in the world are:

- the future of e-commerce is forecast for mobile e-commerce implementation and payment transactions using smartphones, tablets and other mobile devices, as a share of Internet users using mobile devices is growing;

- a key success factor of e-commerce businesses in modern conditions is personalization, individualization. In recent years customers of ecommerce businesses are increasingly interested in unique products designed in sites by themselves or other consumers. In case of rapid growth of such orders, problems with satisfying all users' desires may occur;
- more and more retailers are trying to enable their customers to order products via the Internet, besides offer favorable terms of same-day delivery products, free exchange and return of goods that undoubtedly is their competitive advantage. Although at present the share of online retail turnover in the total volume of retail trade in Ukraine is low $-1.5-2 \%$, there is a great growth potential of this figure, as in developed countries the figure is not less than $7,8 \%$;

- widespread use of electronic money and other new means of payment, putting into circulation own currency by e-commerce companies. A good representative of e-commerce businesses is Amazon that has been using its own currency Amazon Coins since 2013. This type of virtual currency is used to purchase mobile apps and make purchases with their use;

- the use of new technologies to promote products online. The introduction of 3D technology for simulating in kind products in the network in order to provide them with more complete description attractive for new customers; the introduction of technology with the ability to view video switching in one click from video viewing to the Internet-shop to purchase a particular product;

- the active development of e-commerce through social networks. E-commerce businesses use social networking as a marketing platform for promoting their online stores, increasing the number of customers, examining their preferences, developing personalized offers on the received data basis, offering consumers to generate wish-lists or to become familiar with goods and services recommended by friends. For example, eBay is working on product recommendations based on Facebook data, Walmart has 22 million fans in Facebook and constantly surveys to determine the range of products offered on the site;

- among the population of developed countries a new life style "on-line" is spreading, ordinary citizens are turning to the network not only for information but also for purchasing goods, banking operations and other activities;

- the form of interaction between enterprises as e-commerce B2B is actively developing;

- business to business, e-commerce opportunities are widely implemented not only in retail practice for customers;

- continuous updating and development of new information technology and computer technology that facilitate access to the users' network and establish closer cooperation. 
As a country-innovator the USA made a great leap in the implementation of virtual economy. E-business has become a powerful industry there. Experts predict that e-business will have reached the level of 20 trillion dollars by 2020 that exceeds twice GDP of the United States in 2005.

Europe, being involved in the World Wide Web later, today demonstrates the intense growth trends. The highest Internet penetration over $80 \%$ is typical for the Netherlands, Germany, Britain, France, that's why these countries have the highest percentage of consumers who deal with e-commerce businesses (Fig. 1). According to the Center for Retail Research, e-commerce share in total retail trade is the largest in the UK $-13,5 \%$, second place is taken by the USA with $11,6 \%$, the third is Germany $-9,7 \%$. Next in the list are the countries with approximate share of e-commerce $7 \%$ of the total retail turnover Sweden, France, the European Union. For Italy, Russia, Poland and Spain the figure was at 2,3\%. The average cost of one purchase online in 2013-2014 was the highest in the USA - 119 dollars, while the average number of acquisitions during a year was 15.6 times, while in the UK these indicators were: 99 dollars and 18 times, respectively, in Germany 89 dollars and 18,1 times, in Italy - 72 dollars and 10.4 times, respectively. In the USA the most popular products include digital content, digital appliances, toys, hobbies, books and magazines. The average cost of purchases accomplished depended on the level of prices for goods and services and the solvency of the population, so the figure is highest in the countries with higher levels of economic development.

One of the trends in the field of e-business is the massive use of mobile devices to perform business transactions online (Fig. 2). Turnover within the mobile segment of e-commerce in the USA in 2013 reached 41 billion dollars or $8 \%$, moreover, its growth is predicted to be $100 \mathrm{bln}$. dollars by 2017 , followed by the UK with $10 \%$, Australia $-8 \%$ and the USA $-8 \%$. The share of mobile customers is significantly lower in Germany $6 \%$, Italy $-4 \%$, the Netherlands $-4 \%$, and in France only $2 \%$. It should be noted that only $17 \%$ of French Internet users use their mobile devices to research products while in most European countries the figure is over $30 \%$. In addition, only $4 \%$ of respondents in France said they downloaded and used mobile application retailers (compared to $13 \%$ in Germany and $20 \%$ in the UK). According to eMarketer research, most e-commerce consumers still prefer to use tablets for purchasing rather than smartphones.

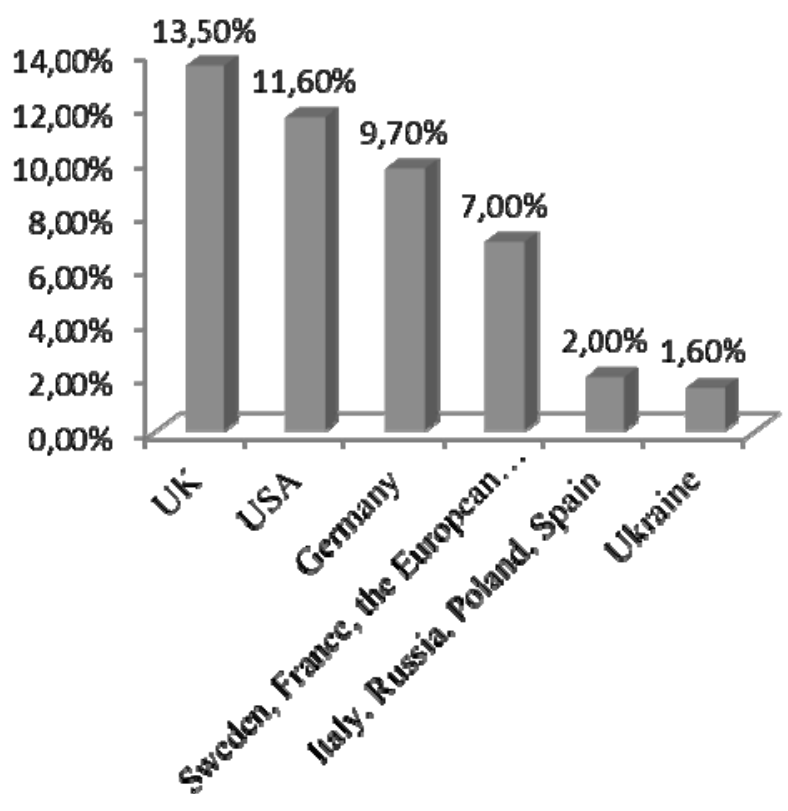

Fig. 1. Internet penetration in the retail world

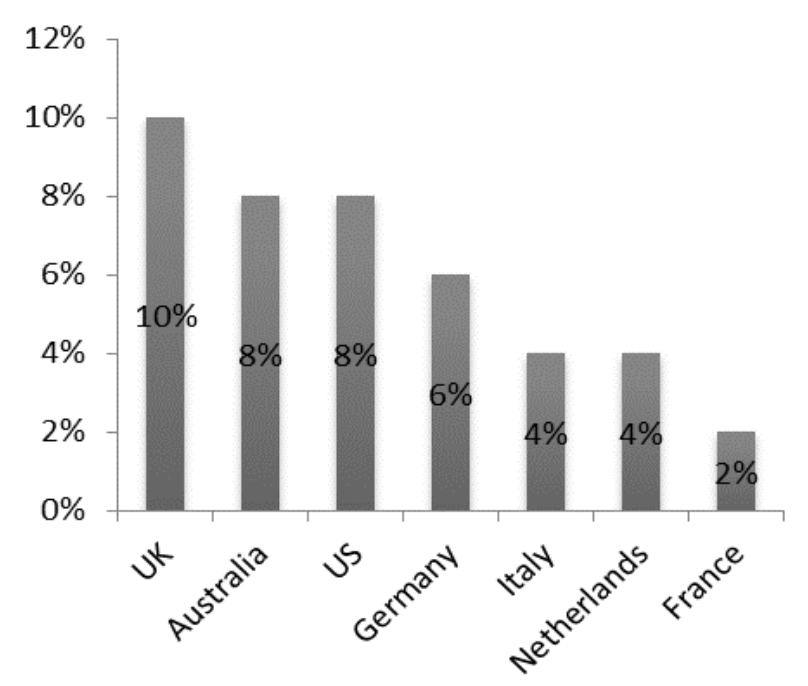

Fig. 2. The share of "mobile" transactions in e-commerce in 2015

According to eMarketer research, the first in the rating of the countries with the developed e-commerce is the United States, the second is China. We note that the Chinese e-commerce market has great potential. It is expected to become the world leader by 2016. Dynamically growing e-commerce markets in China, India and Indonesia will have allowed the Asia-Pacific region to be ahead of other regions at the pace of e-business development by 2017. Compared to the US and European e-commerce market, e-business market in India was insignificant in 2012 and amounted to $1.6 \mathrm{bln}$. dollars, but experts predict that its volume may already be $15 \mathrm{bln}$. dollars by 2017 . According to 


\section{O. V. Pyrog, A. I. Horyachka}

ASSOCHAM report \& KPMG Report, in June 2014 the number of online shoppers in India amounted to more than $240 \mathrm{mln}$. people. Indian online market is a combination of individual e-commerce sites and 80 well-known retailers with annual sales of about 100 million dollars. It is forecast that in this region mobile segment is the future of e-commerce, namely smartphones, but not more expensive laptops and tablets. Among the clients of Indian e-commerce companies there are $90 \%$ of people aged 18-35 years. In Asian countries the rapid pace of online business is related to the fact that many consumers have only recently gained access to the network, and therefore actively began to perform the first e-commerce operations while Internet penetration was only about $17 \%$.

Asian countries along with Argentina, Mexico, Brazil, Russia, India and Canada will encourage the growth of e-commerce worldwide. According to forecasts of Forrester Research, the total turnover of e-commerce in Argentina, Brazil and Mexico in 2018 will grow by $135 \%$ and will amount to 47 billion. dollars. Brazil is a leader among countries of the South American region. Its e-commerce market $(\mathrm{B} 2 \mathrm{C}+\mathrm{C} 2 \mathrm{C})$ will have grown for 5 years to more than 2 times from $15 \mathrm{bln}$. to 35 bln. dollars. The number of online shoppers during the same period will have increased by $79,3 \%$, from 30.9 million people to 55.4 million.

It is expected that China will have become the world largest retail market by 2018. In particular, for 2015-2016 the growth of retail volume in China will be $8,7 \%$. In the future, the share of mobile payment transactions in total retail trade in the country will increase from $8 \%$ to $20-30 \%$.

The number of online shoppers is rapidly growing (Fig. 3). In 2010 there were 140 million people involved in e-commerce in China, in 2012-220 million people and by 2015 their number is expected to increase to 520 million. In the USA the number of online shoppers will have increased from 140 million to 200 million people by 2015 .

In Ukraine the volume of e-commerce in 2013 was estimated at 2 billion dollars that was by 1 billion dollars more compared to the previous year. Ukrainian market has the rapid pace of development and future prospects. However, due to the general decline of the Ukrainian economy against a difficult social and political situation development of e-business significantly reduced its pace. Because of the annexation of the Crimea and the war in the east in 2014 volumes of e-commerce decreased to 1.6 billion dollars according to preliminary estimates, besides population's solvency was reduced. The average order value in Internet-shops decreased in proportion to the fall of the national currency to $60 \%$, consumers of category "luxe" instead of buying exclusive products started buying their cheaper counterparts. Due to fluctuations in exchange rates, domestic participants of e-commerce market suffer from reducing returns and losses. So one of the trends of domestic e-commerce is a rapid reorientation to new types of goods and services, flexible pricing depending on exchange rate.

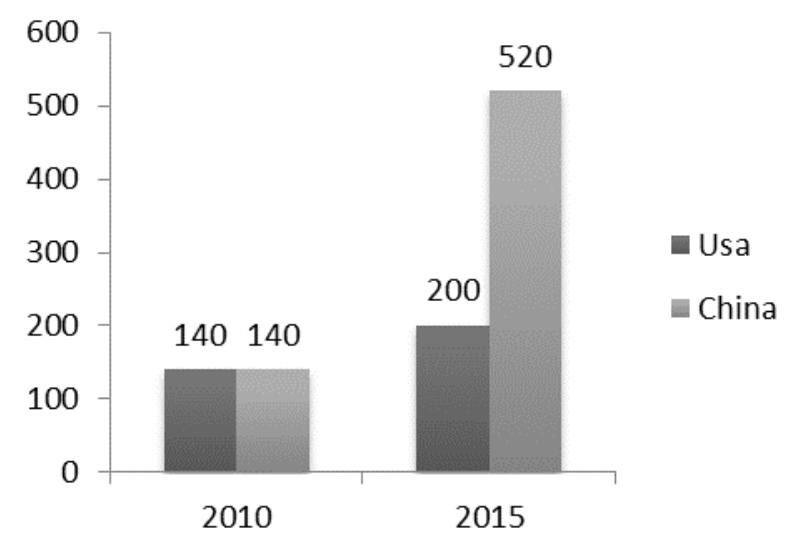

Fig. 3. Dynamics of the number of online shoppers in the USA and China

The Internet is undoubtedly the most massive technology and hence the most promising one in terms of investment and business.

Now there is the fourth industrial revolution based on computerization of production. It involves implementing cyber physical systems (CPS) in production and logistics, as well as using the Internet in industrial processes.

By combining machines, storage systems and equipment in a network, we get the "intellectual production", in which machines independently exchange information and are constantly adapted to the urgent production needs. As a result, experts expect to receive rapid productivity growth as well as significant savings in materials and electricity.

German Management Academy of Lower Saxony supports specialists and managers through its training program Related Industry 4.0. Foreign countries show a great interest in this strategy that gives German industry outstanding opportunities for optimal placement in world production. 
In practice-oriented DMAN seminars, which include informational visits to German companies, managers from Central and Eastern Europe, Asia and the Middle East become more familiar with the strategy of Idustry 4.0 and learn best practices in place.

In recent years the developed countries of the world have defined strategy and tactics of their information development and adopted documents (including concepts) in this field of public life. For example, the United States has a program "Action Plan of the US Administration in the National Information Infrastructure". The European Union has developed the program "European Way to the Information Society." At the end of June 2000 the Action Plan "e-Europe" was adopted. At the level of the Member States of the European Community the legal regulation was introduced. In particular, Germany introduced the program "Germany's path to the information society". In the Nordic countries there is also a legal regulation on the issues of establishment and development of the information society. For example, in Norway there is a program of formation and transition to an information society "Better use of information technology in Norway" and the "eNorge". The formation of Norwegian appropriate strategies and tactics in the field of information and communication technologies were due to the initiative of the European Union "eEurope". The "eNorge" was implemented within the above Action Plan of the European Community with adaptation to the conditions of Norway, which was primarily provided by the program. In the program "eNorge" government planned intention to achieve the goal of an information society and knowledge society in three main requirements that must be guaranteed "access competence - confidence" [3]. There is a program of Denmark "State program of transition to an information society", and in Sweden there was adopted National strategy for the information society and the Swedish program "Information Society Sweden". Finland has introduced two programs: Program "Finnish way to the information society" and, accordingly, Information Society Development Program and Strategy of Information Society by 2015.

Nowadays the main trends of e-commerce market in the world are:

- steady flow of retail trade to the Internet (now in Ukraine the share of Internet sales is $1,6 \%$, in the UK $-13 \%)$;
- increase in the share of active customers among Internet users;

- habit to use the network as a way of searching information about the product (typical for Ukraine, because 56-60 \% Ukrainians use search engines to gather information, 33-41\% of Europeans and $28 \%$ of Americans);

- trend aimed at developing ways to pay online (today over $85 \%$ of purchases are made in cash);

- development of advertising on the Internet.

\section{Conclusions}

E-business is a profitable area for investment because it is developing rapidly. The most promising market is China, it has the highest growth rate of ecommerce indicators in the world. Now we are observing a revolution - Industry 4.0, which will allow to develop information technology to the level of intellectual production. The virtual economy will eventually replace the real economy.

\section{References}

1. Patramanska L. Yu. (2014) Research current trends in the world market for e-commerce / L. Yu. Patramanskall Technology audit and production reserves. - 2014. - No. 5/3 (19). - p. 111.

2. Kudinov O. (2011) ecommerce development in conditions of global information space / O. Kudinov // Bulletin of the International Nobel Economic Forum. - 2011. - No. 1(4). - P. 196-202.

3. Kredenets A. (2011) Status and trends in the development of e-retail sector in the Ukrainian network Internet / E. V. Kredenets // Bulletin of Lviv Commercial Academy. - 2011. - No. 34. - P. 268-272.

4. Chuchko N. A. (2011) Ecommerce system of global economic relations / N. A. Chuchko, G. M. Lozikova // Industrial economics. - 2011. - No. 4. - P. 153-158.

5. Voznyy M. I. (2011) International e-commerce. Problems and prospects of development in Ukraine / M. I. Voznyy // Proceedings of Bukovina University. Economic science. - 2011. - No. 7. - P. 243-252.

6. Summer A. (1999) E-Commerce / A. Summer, Gr. Dunkan. - NYH Publishing, 1999. - 263 p.

7. Hubaev G. N. (2005) Information marketing of products / G. N. Hubaev. - Rostov-on-Don: “RYNH”, 2005. - $224 p$.

8. Tardaskina T. N. (2011) Commerce / T. N. Tardaskina, E. M. Strelchuk, V. Tereshko. - Odessa: ONAT. Popov, 2011. - 244 p.

9. Global Retail E-Commerce Index [Electronic resource]. - Access mode: www/URL:http://www. atkearney.com/consumerproducts-retail/ecommerce-index.

10. Worldwide Ecommerce Sales to Increase Nearly $20 \%$ in 2014 [Electronic resource]. - Access mode: 


\section{O. V. Pyrog, A. I. Horyachka}

http://www.emarketer.com/Article/Worldwide-

Ecommerce-Sales-Increase-Nearly-20-2014 / 1011039

11. E-Commerce Europe. European B2C E-commerce Report 2014 [Electronic resource]. - Access mode: www.ecommerce-europe.eu/facts-figures

12. IT market in Ukraine 2014 - Current situation and short term outlook [Electronic resource]. - Access mode: www.ewdn.com/category/data-reports

13. Morgan Stanley Blue Papers [Electronic resource]. - Access mode: www.morganstanley. com/views/perspectives

14. Ovchinnikov B. A. (2014) Marketplace e-commerce in Russia. 9 months in 2014: Manuscript, Question and Answer [Electronic resource] / B. Ovchinnikov. Access mode: www.datainsight.ru/eretailforum 2014

15. KPMG-ASSOCHAM India Luxury summit in 2014 [Electronic resource]. - Access mode: www. kpmg. com/IN/en/IssuesAndInsights/ArticlesPublications/ Documents/KPMG-ASSOCHAM-India-LuxurySummit-2014.pdf

16. Wigder Z. D. (2014) The Evolution Of eCommerce In Brazil [Electronic resource] / Z.D. Wigder. Access mode: www.forrester.com/The+ Evolution + Of + eCommerce + In + Brazil / fulltext / - / E-RES 117444 